\title{
Paket Pelatihan Coping Self-Talk bagi Calon Konselor
}

\author{
Irene Maya Simon ${ }^{1}$, Diniy Hidayatur Rahman ${ }^{1}$, Nugraheni Warih Utami ${ }^{1}$, Eko P. Laksana ${ }^{1}$ \\ ${ }^{1}$ Bimbingan dan Konseling-Universitas Negeri Malang
}

\begin{tabular}{l}
\hline \hline INFO ARTIKEL \\
\hline Riwayat Artikel: \\
Diterima: $17-01-2020$ \\
Disetujui: $22-04-2020$ \\
\hline
\end{tabular}

\section{Kata kunci:}

training package; coping self-talk; prospective counselor; paket pelatihan: coping self-talk; calon konselor

\begin{abstract}
ABSTRAK
Abstract: This study aims to develop a training package of coping self-talk for preservice counselors that has high acceptability, i.e. meeting the criteria of appropriateness, usefulness, easiness, attractiveness and clarity. The study applied a research and development design and procedure adapted from Borg \& Gall. The evaluation of the training package was carried out through expert judgement and field testing. Two experts in guidance and counseling and one expert in instructional media were asked to validate the training package. Next, a lecturer and ten undergraduate students majoring in guidance and counseling were involved in small group testing. After making the necessary revisions, a lecturer and 39 other students were involved in operational field testing. The series of examinations produced a training package of coping self-talk that meets the criteria of appropriateness, usefulness, easiness, attractiveness and clarity.
\end{abstract}

\begin{abstract}
Abstrak: Penelitian ini bertujuan untuk menghasilkan paket pelatihan coping self-talk bagi calon konselor yang mempunyai akseptabilitas tinggi, yaitu memenuhi kriteria ketepatan, kegunaan, kemudahan, kemenarikan, dan kejelasan. Penelitian ini menggunakan desain dan prosedur penelitian pengembangan yang diadaptasi dari Borg \& Gall. Pengujian bahan pelatihan dilakukan dengan uji ahli dan uji lapangan. Dua ahli bimbingan dan konseling dan seorang ahli media pembelajaran diminta untuk memvalidasi paket pelatihan. Berikutnya, seorang dosen dan sepuluh mahasiswa BK terlibat dalam pengujian kelompok kecil. Setelah dilakukan revisi produk yang diperlukan, pengujian lapangan operasional dilakukan oleh seorang dosen dan 39 mahasiswa BK lainnya. Serangkaian uji coba tersebut menghasilkan produk paket pelatihan coping self-talk yang memiliki kriteria sangat tepat, sangat berguna, sangat mudah, sangat menarik, dan sangat jelas.
\end{abstract}

\author{
Alamat Korespondensi: \\ Irene Maya Simon \\ Bimbingan dan Konseling \\ Universitas Negeri Malang \\ Jalan Semarang 5 Malang \\ E-mail: irene.maya.fip@um.ac.id
}

Konselor adalah profesi yang dituntut untuk membantu konseli agar dapat berkembang secara optimal (Hariko, 2017). Dalam proses membantu konseli, konselor harus memiliki keterampilan khusus dan khas. Keterampilan tersebut adalah keterampilan konseling. Keterampilan konseling mutlak dimiliki oleh mahasiswa Jurusan BK untuk dapat berperan penting dalam membantu siswa. Keterampilan konseling yang dimiliki oleh calon konselor tersebut tidak hanya kemampuan dalam menguasai teori komunikasi konseling dan menguasai teori pendekatan-pendekatan konseling saja, tetapi lebih kepada bagaimana calon konselor dapat secara tepat menggunakan proses konseling untuk memahami dan membantu konseli. Salah satu keterampilan yang harus dikuasai adalah bagaimana calon konselor dapat menguasai diri dan pemikirannya sehingga ia dapat memahami konseli secara tulus dan menerimanya tanpa syarat.

Keterampilan menguasai pikiran dikenal dengan istilah mind skills atau keterampilan mengelola pikiran. Keterampilan pengelolaan pikiran tersebut memengaruhi bagaimana calon konselor mampu berinteraksi secara tepat dengan konseli. Interaksi yang muncul dalam proses konseling menjadi sangat hangat dan menyenangkan atau menjadi dingin dan tidak berdampak bagi konseli ditentukan dari bagaimana calon konselor dapat menguasai pemikirannya dan mengendalikan pemikirannya selama proses konseling.

Salah satu pemikiran yang berbentuk verbal disebut self-talk. Self-talk adalah apa yang dikatakan individu pada dirinya sendiri sebelum, selama, dan setelah situasi tertentu. Dengan self-talk, seseorang akan mampu merasakan diri yang sehat (Rosenberger, 2011). Kemampuan untuk mengatur self-talk disebut coping self-talk. Coping self-talk diperlukan oleh calon konselor untuk dapat mengelola semua pikiran yang diverbalisasi dalam diri, baik secara negatif maupun positif, bahkan untuk mengatasi stress (Aselton, 2012). Dengan kemampuan mengelola self-talk secara tepat, maka calon konselor dapat membantu konseli secara tepat melalui proses konseling yang membantu (Atmoko et al., 2018). 
Self-talk merupakan sebuah strategi yang dapat digunakan untuk mengubah perilaku dengan mengurangi gangguan untuk menghadapi masa depan dengan lebih baik (Cutton et al., 2015). Self-talk merupakan kata-kata yang kita katakan pada diri kita sendiri. Kata-kata tersebut menggambarkan dan menciptakan pernyataan-pernyataan yang emosional. Seseorang dapat merasa percaya diri, nervous, termotivasi, dan kecil hati semua bergantung pada apa yang dikatakan pada dirinya sendiri. Selama ini, coping self-talk belum tergarap dengan tepat dalam perkuliahan teori maupun praktik konseling. Seringkali matakuliah teori maupun praktik konseling lebih berfokus pada bagaimana mahasiswa Jurusan BK dapat menguasai teori komunikasi dan pendekatan konseling serta dapat mempraktikkannya dengan baik. Kenyataannya, ketika secara verbal mereka melakukan konseling, mind skills belum terurus dan dibahas lebih dalam. Pelaksanaan praktik konseling menjadi formalitas mahasiswa dalam memenuhi tugas daripada memahami dengan benar bagaimana mengelola mind skills tersebut agar pelaksanaan konseling benar-benar dapat nyaman dan tepat.

Pelatihan coping self-talk yang perlu dilakukan membutuhkan panduan untuk dapat memudahkan mahasiswa dalam memahami dan berlatih mengelola self-talk. Panduan pelatihan coping self-talk ini menggunakan pembelajaran Structured Learning Approach (SLA) untuk dapat memberikan gambaran secara tepat mengenai pelatihan coping self-talk. SLA digunakan dalam panduan ini karena dapat mengajarkan cara melakukan coping self-talk melalui instruksi, modelling, role playing, feedback dan transfer of training secara bertahap, untuk memberikan pemahaman yang tepat dan memberikan kesempatan untuk mempraktikkan secara langsung saat pelatihan.

Beberapa penelitian terdahulu telah membuktikan bahwa SLA merupakan pendekatan yang efektif untuk melatihkan keterampilan-keterampilan. Rahayu, Mappiare-AT, \& Triyono (2018) membuktikan bahwa SLA efektif untuk meningkatkan perilaku asertif. Penelitian lain yang dilakukan oleh Hardianti (2018) juga membuktikan bahwa SLA dapat digunakan untuk melatihkan keterampilan mind mapping untuk meningkatkan keterampilan academic goal setting. Ramli, Hidayah, \& Fauzan (2018) juga menemukan bahwa SLA efektif untuk meningkatkan kompetensi konselor dalam melakukan konseling dengan pendekatan Solution-Focused Brief Counseling (SFBC). Temuan-temuan tersebut membuktikan bahwa SLA adalah pendekatan yang efektif untuk melatihkan keterampilan-keterampilan, baik dalam setting konseling maupun latar pembelajaran. Dengan demikian, SLA diyakini efektif untuk melatihkan keterampilan mind skills dalam paket pelatihan ini. Berdasarkan deskripsi latar belakang tersebut, penelitian pengembangan ini bertujuan untuk menghasilkan paket pelatihan coping self-talk bagi calon konselor yang mempunyai akseptabilitas yang tinggi, yaitu memenuhi kriteria kegunaan, kelayakan, ketepatan melalui uji ahli, dan uji pengguna.

\section{METODE}

Penelitian ini menggunakan desain dan prosedur penelitian pengembangan yang dikemukakan oleh Borg \& Gall (1983). Kegiatan penelitian diawali dengan pengumpulan informasi atau need assessment pada 60 mahasiswa Jurusan BK Universitas Negeri Malang angkatan 2014. Instrumen yang digunakan untuk need assessment ini adalah angket dan pedoman wawancara yang dikembangkan berdasarkan indikator pengembangan paket pelatihan coping self-talk bagi calon konselor. Setelah data need assessment dikumpulkan, selanjutnya dilakukan analisis data. Data hasil analisis need assessment digunakan sebagai dasar pengembangan panduan. Analisis data dilakukan secara kuantitatif dan kualitatif. Data berupa komentar, saran, dan kritik dianalisis secara kualitatif. Data kuantitatif dilakukan dengan menggunakan model kesepakatan (inter-rater agreement model).

Tahap perencanaan penelitian dilakukan untuk merumuskan tujuan dan prosedur penelitian. Seperti telah disebutkan sebelumnya, tujuan penelitian ini adalah pengembangan paket pelatihan coping self-talk bagi calon konselor. Prosedur yang dipilih dalam pelatihan ini adalah dengan menggunakan bimbingan kelompok dengan strategi SLA.

Tahap penyusunan prototipe produk paket pelatihan coping self-talk bagi calon konselor terdiri dari beberapa bagian, yaitu Kata Pengantar, Daftar Isi, dan Pendahuluan. Bagian pendahuluan, meliputi rasional, tujuan, sasaran, petunjuk umum yang berisi tentang ruang lingkup paket pelatihan, pendekatan, dan alokasi waktu, langkah-langkah pelatihan, berisi tentang penerapan empat dimensi coping self-talk yang dilatihkan melalui strategi SLA, yaitu tahap 1: penjelasan materi, tahap 2: pemberian model, tahap 3: bermain peran, tahap 4: pemberian umpan balik, dan tahap 5: pemberian tugas dan pemeliharaan, dan Daftar Pustaka.

Tahap validasi ahli dilakukan dengan melibatkan dua Ahli BK dan satu Ahli Media. Berdasarkan penilaian, masukan dan saran para ahli, dilakukan proses perbaikan terhadap paket pelatihan coping self-talk yang dikembangkan. Revisi ini dilakukan sesuai dengan masukan dari para ahli agar paket pelatihan valid dan layak diujicobakan.

Pada tahap uji coba kelompok kecil (uji coba calon pengguna), produk diujikan pada seorang dosen/trainer dan sepuluh mahasiswa. Uji coba kelompok kecil ini dilakukan untuk mengetahui tingkat ketepatan, tingkat kemudahan, tingkat kemenarikan paket pelatihan, serta saran dan tanggapan mahasiswa tentang paket pelatihan ini. Berdasarkan hasil uji coba kelompok kecil, akan dilakukan perbaikan atau penyempurnaan paket pelatihan. Proses perbaikan terhadap produk akhir dilakukan berdasarkan saran pada uji coba lapangan kelompok kecil. Setelah melakukan perbaikan hasil uji coba kelompok kecil, paket pelatihan yang dikembangkan diuji-coba di lapangan operasional oleh seorang dosen/trainer dan 39 mahasiswa. Uji 
coba lapangan operasional ini dilakukan untuk mengetahui tingkat ketepatan, tingkat kemudahan, tingkat kemenarikan paket pelatihan, serta saran dan tanggapan siswa tentang paket pelatihan ini. Revisi terhadap produk akhir dilakukan berdasarkan saran-saran dari hasil uji coba lapangan operasional.

\section{HASIL}

Berdasarkan penilaian dua ahli materi BK yang dianalisis dengan menggunakan inter-rater agreement model dengan menggunakan kategori indeks yang mengacu pada pengklasifikasian yang dikemukakan oleh Guilford (1950), produk memiliki relevansi tinggi dari kedua ahli yaitu 31. Dilanjutkan dengan penghitungan indeks uji ahli materi yang memperoleh indeks sebesar 0,97. Berdasarkan pengklasifikasian inter-rater, paket pelatihan yang dikembangkan memiliki validitas yang sangat tinggi. Hal ini menunjukkan bahwa paket pelatihan coping self-talk bagi calon konselor ini secara umum tidak ada yang perlu direvisi, sehingga paket pelatihan coping self-talk ini relevan untuk digunakan oleh calon konselor.

Berdasarkan data penilaian dari uji ahli media, dipaparkan bahwa paket pelatihan coping self-talk bagi calon konselor dari aspek ketepatan mendapatkan nilai rata-rata 3,9. Berdasarkan kriteria yang telah dibuat, skor tersebut menunjukkan bahwa paket pelatihan diinterpretasikan sangat tepat bagi calon konselor. Pada aspek kemudahan, paket pelatihan ini mendapatkan nilai rata-rata 4 yang menunjukkan bahwa paket pelatihan ini sangat mudah untuk digunakan oleh calon konselor. Pada aspek kemenarikan, paket pelatihan ini mendapatkan nilai rata-rata 4 yang berarti bahwa paket pelatihan ini sangat menarik. Pada aspek sistematika, paket pelatihan ini mendapatkan nilai rata-rata 4 yang dapat diinterpretasikan bahwa sistematika paket pelatihan ini sangat jelas. Berdasarkan analisis data dari uji ahli media tersebut, dapat diketahui bahwa paket pelatihan coping self-talk bagi calon konselor ini merupakan media pelatihan yang sangat tepat, sangat mudah, sangat menarik, dan sangat jelas bagi mahasiswa.

Berdasarkan penilaian dari uji calon pengguna (dosen), dipaparkan bahwa paket pelatihan coping self-talk bagi calon konselor ini mendapatkan nilai rata-rata 4 dalam aspek kegunaannya. Berdasarkan kriteria yang telah dibuat, skor tersebut menunjukkan bahwa paket pelatihan sangat berguna bagi mahasiswa. Pada aspek ketepatan, paket pelatihan ini mendapatkan nilai rata-rata 3,6 yang dapat diinterpretasikan bahwa paket pelatihan ini sangat tepat bagi mahasiswa. Pada aspek kemenarikan, paket pelatihan ini mendapatkan nilai rata-rata 3,4 yang menunjukkan bahwa paket pelatihan ini sangat menarik. Adapun pada aspek sistematika, paket pelatihan ini mendapatkan nilai rata-rata 3 yang dapat diinterpretasikan bahwa sistematika paket pelatihan ini tergolong jelas. Berdasarkan analisis data dari uji calon pengguna (dosen) tersebut, dapat diketahui bahwa paket pelatihan coping self-talk bagi calon konselor merupakan media pelatihan yang sangat berguna, sangat tepat, sangat mudah, sangat menarik, dan jelas. Hal ini menunjukkan bahwa paket pelatihan coping self-talk bagi calon konselor ini tidak perlu direvisi.

Dari hasil penilaian uji coba calon pengguna II (calon konselor) yang terdiri dari sepuluh mahasiswa Jurusan BK UM angkatan 2014, dapat diketahui bahwa rerata penilaian paket pelatihan coping self-talk pada aspek ketepatan bahasa yaitu 3,2; rerata pada aspek ketepatan tujuan 3,5; rerata pada aspek kemudahan langkah yaitu 3,2; rerata pada aspek kegunaan isi yaitu 3,8; rerata pada aspek kemenarikan isi yaitu 3,3; rerata pada aspek kegunaan evaluasi dan latihan yaitu 3,3; rerata pada aspek kemudahan bahasa yaitu 3,6; dan rerata pada aspek kemenarikan warna adalah 2,6. Dengan demikian, dapat diketahui bahwa paket pelatihan coping self-talk bagi calon konselor ini dinyatakan tepat dari segi bahasanya, sangat tepat rumusan tujuannya, mudah langkah-langkahnya, sangat berguna isinya, sangat menarik isinya, sangat berguna evaluasi dan latihannya, sangat mudah bahasanya, dan menarik perpaduan warnanya.

Uji lapangan operasional bertujuan untuk mengetahui keefektifan pelatihan coping self-talk bagi calon konselor sehingga di awal kegiatan calon konselor mengisi angket self-talk untuk mengetahui kondisi self-talk negatif mereka. Subjek uji lapangan operasional ini sebanyak 39 orang. Dari hasil pretest diketahui bahwa sepuluh orang memiliki self-talk negatif yang tinggi, sedangkan 29 orang lainnya memiliki self-talk negatif yang sedang.

Setelah pretest, kegiatan dilanjutkan dengan pelatihan yang diawali dengan penjelasan tentang tujuan pelatihan dan garis besar kegiatan. Tahapan selanjutnya yang dilakukan adalah penjelasan materi atau arahan tentang hakikat coping self-talk, dilanjutkan dengan self-talk negatif, dan dimensi coping self-talk. Dalam tahap penjelasan materi, digunakan metode ekspositori dengan media powerpoint dan disertai dengan contoh-contoh konkret yang terjadi, baik dalam kehidupan sehari-hari maupun dalam proses konseling. Calon konselor diberikan kesempatan untuk bertanya di akhir penjelasan dan diberikan penjelasan lagi terkait hal-hal yang belum dimengerti.

Tahap selanjutnya adalah pemberian model, dimana calon konselor dibimbing untuk memahami kemunculan self-talk negatif dan memberikan penjelasan terhadapnya serta membuat rancangan coping self-talk. Hal ini dilakukan melalui pengisian form 3R. Setelah seluruh calon konselor memahami kegiatan ini, pelatihan dilanjutkan ke tahap bermain peran. Pada tahap ini, calon konselor diminta untuk melakukan konseling individu dengan rekan lainnya secara bergantian. Dalam konseling tersebut, mahasiswa diberikan tugas untuk mengamati self-talk negatif yang muncul dan segera mencatatnya. Setelah permainan peran selesai, para calon konselor tersebut diminta untuk melengkapi kolom 3R lainnya, yaitu rasional dan rancang. 
Pelatihan dilanjutkan ke tahap pemberian umpan balik. Pada tahap ini, calon konselor diberikan beberapa pertanyaan evaluatif terkait pengalaman mereka mengamati self-talk disela-sela proses konseling, yaitu kendala dan hal yang mendukung dalam mengamati self-talk. Selain itu, calon konselor juga diberi pertanyaan evaluatif terkait pengisian form 3R untuk memberikan penjelasan tentang self-talk negatif dan coping self-talk yang diperlukan serta merancang coping self-talk. Setelah itu, calon konselor diberi penjelasan kembali tentang materi yang belum dipahami.

Tahap akhir pelatihan ialah pemberian tugas dan pemeliharaan. Pada tahap ini, kegiatan diawali dengan penyampaian kesimpulan atas kegiatan yang telah dilakukan dan kemudian pemberian tugas kepada calon konselor untuk melakukan pengamatan atas kemunculan self-talk secara khusus ketika proses konseling berlangsung dan kemudian mencoba melengkapi form 3R. Hal ini perlu dilakukan oleh calon konselor agar mereka menjadi peka terhadap kemunculan self-talk negatif dan dapat segera menggantinya dengan coping self-talk. Pada akhir pertemuan, calon konselor diberikan posttest untuk melihat kemunculan self-talk negatif mereka.

Setelah data kuantitatif diperoleh, para ahli, para subjek uji kelompok kecil (dosen dan calon konselor), dan para subjek uji lapangan operasional memberikan penilaian dan masukan yang bersifat kualitatif untuk perbaikan paket pelatihan coping self-talk. Hasil penilaian dari semua ahli dan calon pengguna menghasilkan beberapa saran, yaitu (1) perlu adanya penambahan jumlah waktu pelatihan; (2) pada tahap pemberian model perlu ditambahkan contoh-contoh tentang jenis self-talk negatif dan juga dimensi-dimensi coping self-talk; (3) pada kolom Rasional pada tahap 2 perlu diberikan penjelasan yang detail sehingga para calon konselor dapat memahami dengan jelas maksud dan bagaimana cara mengisi kolom tersebut; (4) pada tahap bermain peran, selain menggunakan setting konseling, latihan coping self-talk perlu ditambahkan dengan menggunakan setting kehidupan sehari-hari; (5) sampul paket pelatihan perlu diperhatikan kesesuaiannya dengan tujuan dan isinya dimana lebih ditekankan kepada proses self-talk negatif menjadi coping self-talk dan bukan kepada gambar orangnya; (6) gambar latar paket pada isi pelatihan perlu dipertimbangkan ketajamannya agar pengguna menjadi lebih fokus pada isi, dan bukan pada gambar. Dalam hal ini, warna yang digunakan disarankan untuk lebih dipudarkan sehingga tidak mendominasi warna tulisan yang seharusnya menjadi fokus utama pengguna.

Berdasarkan analisis data uji ahli dan uji coba paket pelatihan coping self-talk tersebut dapat diketahui bahwa produk yang telah dikembangkan ini memiliki kriteria sangat tepat, sangat berguna, sangat mudah, sangat menarik, dan sangat jelas. Namun demikian, beberapa hal perlu direvisi untuk penyempurnaan produk. Revisi dilakukan setelah penilaian dari ahli BK dan ahli media serta calon pengguna produk (dosen).

\section{PEMBAHASAN}

Setelah uji ahli materi dan media, uji calon pengguna, dan uji lapangan operasional, produk mendapatkan enam saran yang kemudian dijadikan acuan untuk merevisi produk. Saran pertama adalah penambahan alokasi waktu. Sesuai dengan saran tersebut, tambahan alokasi waktu diberikan pada penjelasan materi dan pemberian model. Hal ini bertujuan agar calon konselor dapat memahami konsep self-talk dan coping self-talk dengan jelas sebelum mengikuti tahap-tahap pelatihan selanjutnya. Pemberian model juga diberikan tambahan alokasi waktu yang cukup banyak agar calon konselor memperoleh contoh yang cukup dan jelas terkait konsep-konsep yang telah diajarkan (Bradbury, 2016; Bunce et al., 2010; Carriere et al., 2008). Penambahan alokasi waktu pemberian model ini juga terkait dengan saran kedua, yaitu penambahan contoh-contoh self-talk negatif dan dimensi-dimensi coping self-talk. Sesuai saran tersebut, penambahan alokasi waktu diikuti dengan penambahan contoh-contoh self-talk negatif dan dimensi-dimensi coping self-talk secara signifikan. Hal ini akan sangat bermanfaat bagi pengguna produk mengingat hasil-hasil penelitian menunjukkan bahwa modelling (pemberian contoh) merupakan prosedur yang penting dalam membentuk keterampilan dan perilaku (Gading et al., 2017; Kuswara et al., 2018; Sari, 2017).

Saran ketiga adalah tambahan penjelasan detail untuk memandu para pengguna produk dalam mengisi kolom Rasional pada Tahap 2. Pengisian Kolom Rasional ini merupakan prosedur penting dalam Tahap 2. Hal ini dikarenakan rasional akan mendasari isian Kolom Rancangan Tindakan. Oleh sebab itu, para pengguna produk perlu memahami dengan jelas bagaimana cara mengisi Kolom Rasional tersebut. Dalam menanggapi saran ini, penjelasan dan langkah-langkah detail dan sistematis telah ditambahkan pada revisi produk. Hal ini sejalan dengan prinsip shaping dalam mengajarkan perilaku pada Behaviorisme, di mana keterampilan-keterampilan umum akan dipecah menjadi keterampilan dan langkah-langkah kecil yang sangat detail (Martin \& Pear, 2015; Miltenberger, 2011).

Saran keempat adalah penambahan setting kehidupan sehari-hari, disamping setting konseling dalam mempraktikkan coping self-talk (Tahap 3). Sesuai dengan saran tersebut, pada produk yang telah direvisi, latihan coping self-talk (Tahap 3) distruktur untuk dilakukan dalam dua setting, yaitu dalam setting kehidupan sehari-hari lebih dulu, dan kemudian diikuti dengan setting konseling. Sesuai dengan prinsip belajar eksperiensial, individu memang akan lebih mudah belajar jika mereka mengalami langsung apa yang dipelajari (Fraser et al., 2018; Huet, 2018; Wallin et al., 2017). Dalam hal ini, individu akan lebih mudah memahami dan memaknai hasil belajarnya jika setting latihannya adalah kehidupan nyata mereka. Setelah pemahaman dalam setting nyata ini diperoleh, hasil belajar tersebut akan lebih mudah untuk ditransfer ke dalam setting lainnya, yaitu setting konseling. 
Saran kelima adalah perbaikan gambar sampul agar sesuai dengan topik self-talk dan coping self-talk. Sebelum revisi, cover panduan lebih identik dengan bidang kesehatan daripada bidang bimbingan dan konseling. Oleh karena itu, revisi dilakukan dengan menggantinya dengan gambar yang lebih sesuai dan diikuti dengan penyesuaian tata letak dan tata warna. Dari sudut pandang desain, cover buku yang baik adalah cover yang menggambarkan keseluruhan dari isi buku tersebut (Sembodo et al., 2016; Yampbell, 2005; Yanuardi, 2010). Semakin dekat kesesuaian sebuah cover dengan isi buku, semakin baik cover tersebut. Hal ini dikarenakan cover merupakan sesuatu yang menanamkan kesan pertama pada sebuah buku dan isinya.

Saran terakhir adalah perubahan warna latar isi panduan. Sebelum revisi, warna latar tersebut terlalu terang sehingga membuat fokus pada materi terganggu. Revisi dilakukan dengan menyamarkan warna latar sehingga pengguna produk akan menjadi lebih fokus pada isi dan bukan pada latar. Warna adalah salah satu faktor yang memiliki pengaruh cukup signifikan terhadap rasa ketertarikan individu pada media (Obilade \& Burton, 2015; Pantaleo, 2014; Spence \& Velasco, 2018). Selain itu, revisi juga dilakukan dengan menambahkan gambar pada latar panduan. Gambar, dalam hal ini, dapat menarik minat dan menumbuhkan motivasi membaca, dan menambahkan kesan ilustratif pada sebuah tulisan (Cao et al., 2018; Roslina, 2017; Villarreal et al., 2015).

\section{SIMPULAN}

Penelitian dan pengembangan paket pelatihan coping self-talk bagi calon konselor ini telah menghasilkan paket pelatihan coping self-talk yang efektif untuk mengurangi self-talk negatif mahasiswa dan berguna bagi dosen/trainer untuk melatihkan coping self-talk pada mahasiswa calon konselor.

Saran ditujukan pada pengguna paket pelatihan coping self-talk maupun bagi peneliti selanjutnya untuk mengembangkan produk lebih lanjut. Mengingat pentingnya self-talk positif bagi para konselor, para dosen Jurusan BK disarankan untuk membantu para mahasiswa calon konselor untuk dapat mengelola self-talknya dengan melatihkan coping selftalk dengan menggunakan paket pelatihan ini.

\section{DAFTAR RUJUKAN}

Aselton, P. (2012). Sources of Stress and Coping in American College Students Who Have Been Diagnosed with Depression. Journal of Child and Adolescent Psychiatric Nursing, 25(3), 119-123. https://doi.org/10.1111/j.1744-6171.2012.00341.x

Atmoko, A., Indreswari, H., Simon, I. M., Utami, N. W., \& Widyatno, A. (2018). Counselor Self-Talk in Counseling Services. International Conference on Education and Technology (ICET 2018).

Borg, W. R., \& Gall, M. D. (1983). Educational Research: An Introduction. In New York. Longman Publishing.

Bradbury, N. A. (2016). Attention Span During Lectures: 8 Seconds, 10 Minutes, or More? Advances in Physiology Education, 40(4), 509-513. https://doi.org/10.1152/advan.00109.2016

Bunce, D. M., Flens, E. A., \& Neiles, K. Y. (2010). How Long Can Students Pay Attention in Class? A Study of Student Attention Decline Using Clickers. Journal of Chemical Education, 87(12), 1438-1443.

Cao, Q., Han, J.-H., Ding, Y.-Y., Huang, S., \& Liu, C. (2018). Song of Red Pine Woods-Design and Study of Digital Picture Books for Preschool Children on iPad. International Conference of Design, User Experience, and Usability, $158-169$.

Carriere, J. S. A., Cheyne, J. A., \& Smilek, D. (2008). Everyday Attention Lapses and Memory Failures: The Affective Consequences of Mindlessness. Consciousness and Cognition, 17(3), 835-847.

Cutton, D. M., Killion, L., \& Burt, D. (2015). Self-talk Repertoire of Physical Education Teachers: Awareness, Reflection, and Action. Journal of Physical Education, Recreation \& Dance, 86(8), 22-26.

Fraser, K., Tseng, T.-L. B., \& Deng, X. (2018). The Ongoing Education of Engineering Practitioners: How Do They Perceive the Usefulness of Academic Research? European Journal of Engineering Education, 43(6), 860-878.

Gading, I. K., Nisa, U., \& Lestari, L. P. S. (2017). Keefektifan Konseling Behavioral Teknik Modeling dan Konseling Analisis Transaksional Teknik Role Playing untuk Meminimalkan Kecenderungan Perilaku Agresif Siswa Sekolah Menengah Atas. Jurnal Kajian Bimbingan dan Konseling, 2(4), 132-142.

Hardianti, N. (2018). Keefektifan Teknik Mind Mapping dengan Structured Learning Approach dalam Meningkatkan Keterampilan Goal Setting Akademik Siswa SMP. Disertasi tidak diterbitkan. Universitas Negeri Malang, Malang.

Hariko, R. (2017). Landasan Filosofis Keterampilan Komunikasi Konseling. Jurnal Kajian Bimbingan Dan Konseling, 2(2), 41-49. https://doi.org/http://dx.doi.org/10.17977/um001v2i22017p041

Huet, I. (2018). Based Education as a Model to Change the Teaching and Learning Environment in STEM Disciplines. European Journal of Engineering Education, 43(5), 725-740.

Kuswara, R., Hartuti, P., \& Sinthia, R. (2018). Efektivitas Layanan Konseling Kelompok Teknik Modelling dalam Membentuk Keterampilan Kepemimpinan Siswa. Consilia: Jurnal Ilmiah Bimbingan dan Konseling, 1(2), 39-48.

Martin, G., \& Pear, J. J. (2015). Behavior Modification: What it is and how to do it. Psychology Press.

Miltenberger, R. G. (2011). Behavior Modification: Principles and Procedures. Cengage Learning. 
Obilade, T. T., \& Burton, J. K. (2015). A Content Analysis of Instructional Design and Web Design Books: Implications for Inclusion of Web Design in Instructional Design Textbooks. Quarterly Review of Distance Education, 16(3), $27-44$.

Pantaleo, S. (2014). Exploring the Artwork in Picturebooks with Middle Years Students. Journal of Children's Literature, 40(1), $15-26$.

Rahayu, B. L. A., Mappiare-AT, A., \& Triyono. (2018). Keefektifan Structured Learning Approach untuk Meningkatkan Perilaku Asertif Siswa SMA Korban Bullying. Jurnal Pendidikan: Teori, Penelitian, dan Pengembangan, 3(11), 14681471.

Ramli, M., Hidayah, N., \& Fauzan, L. (2018). Effectiveness of Structured Learning Approach to Improve Counselor Competence in Applying Solutions-Focused Counseling. International Conference on Education and Technology (ICET 2018).

Rosenberger, E. W. (2011). Where I End and You Begin: The Role of Boundaries in College Student Relationships. About Campus, 16(4), 11-19. https://doi.org/10.1002/abc.20069

Roslina, R. (2017). The Effect of Picture Story Books on Students' Reading Comprehension. Advances in Language and Literary Studies, 8(2), 213-221. https://doi.org/10.7575/aiac.alls.v.8n.2p.213

Sari, M. R. (2017). Efektivitas Teknik Modeling Simbolis dalam Meningkatkan Keterampilan Komunikasi Interpersonal. Jurnal Riset Mahasiswa Bimbingan dan Konseling, 3(6), 474-483.

Sembodo, K. P., Bahruddin, M., \& Dewanto, T. H. (2016). Perancangan Buku City Guide Wisata Cagar Budaya Kota Surabaya Menggunakan Teknik Ilustrasi Pensil Warna Guna Meningkatkan Daya Tarik Wisatawan. Jurnal Art Nouveau, 5(2), 320 328.

Spence, C., \& Velasco, C. (2018). On The Multiple Effects of Packaging Colour on Consumer Behaviour and Product Experience in the "Food and Beverage" and "Home and Personal Care" Categories. Food Quality and Preference, 68, 226-237. https://doi.org/10.1016/j.foodqual.2018.03.008

Villarreal, A., Minton, S., \& Martinez, M. (2015). Child Illustrators. The Reading Teacher, 69(3), $265-275$. https://doi.org/10.1002/trtr.1405

Wallin, P., Adawi, T., \& Gold, J. (2017). Linking Teaching and Research in an Undergraduate Course and Exploring Student Learning Experiences. European Journal of Engineering Education, 42(1), 58-74.

Yampbell, C. (2005). Judging a Book by its Cover: Publishing Trends in Young Adult Literature. The Lion and the Unicorn, 29(3), 348-372.

Yanuardi, I. (2010). Proses Desain Cover Buku di PT. Galangpress Media Utama Yogyakarta. Yogyakarta: PT. Galang Press. 